\title{
Peran Bidan dalam ASI Eksklusif di Kabupaten Cilacap
}

\author{
Majestika Septikasari \\ STIKES Al Irsyad Al Islamiyyah Cilacap Jl Cerme No 24 Sidanegara Cilacap \\ e-mail: majestika86@gmail.com
}

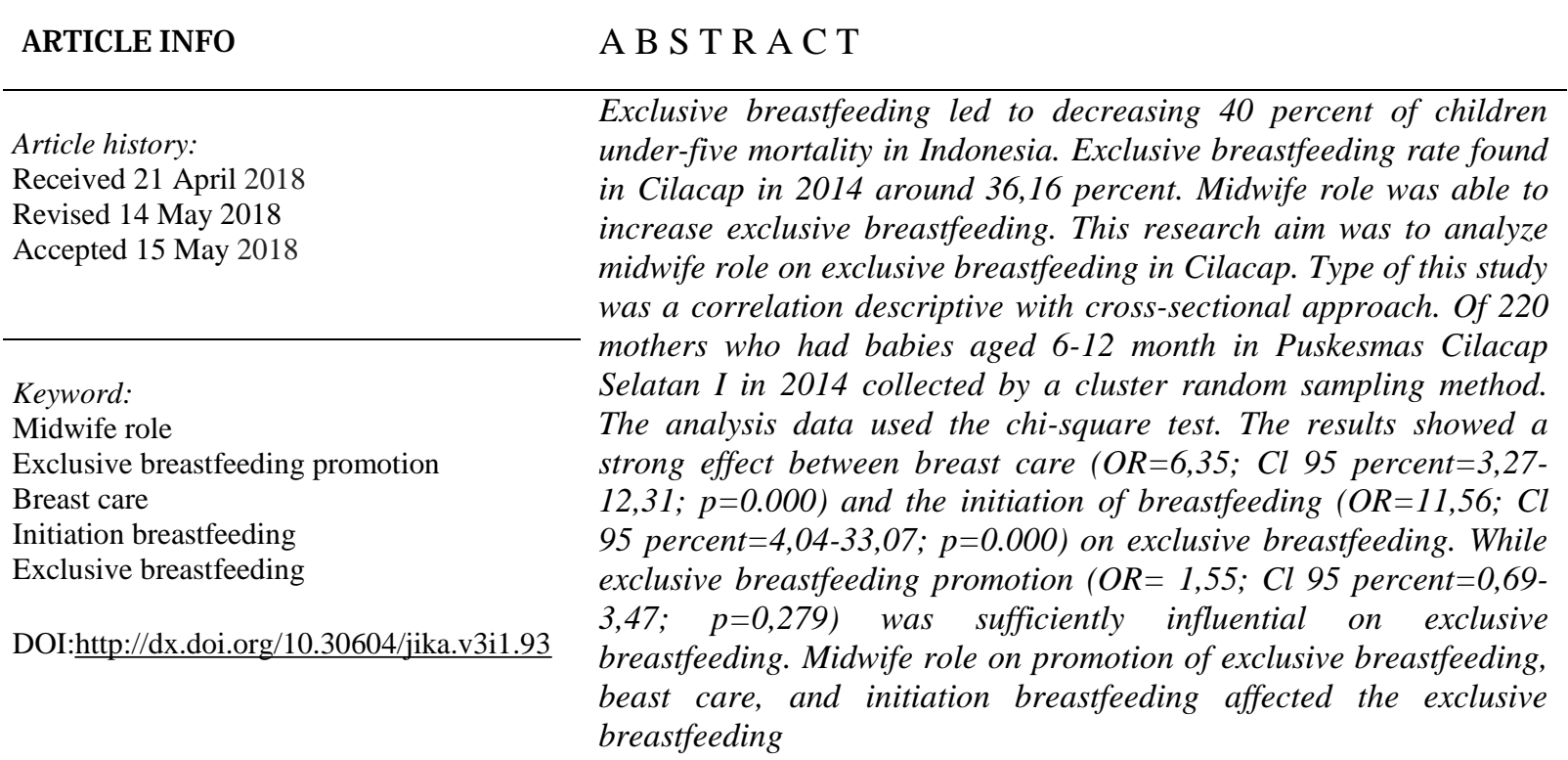

Copyright @ 2018 , Jurnal Aisyah: Jurnal Ilmu Kesehatan. All rights reserved.

\section{PENDAHULUAN}

Air susu ibu (ASI) merupakan makanan tunggal terbaik bagi bayi berusia 0-6 bulan. Pemberian ASI saja sampai bayi berusia 6 bulan atau disebut ASI eksklusif mampu memenuhi seluruh kebutuhan nutrisi bayi. Selain mampu memenuhi kebutuhan nutrisi bayi, ASI eksklusif juga bermanfaat dalam meningkatkan kecerdasan anak (Septikasari, Akhyar, \& Wiboworini, 2016). Aspek fungsi kognitif pada bayi yang di beri ASI eksklusif memberikan hasil lebih baik dibanding dengan yang tidak mendapat ASI eksklusif (Novita, Gurnida, \& Garna, 2008). Manfaat lain dari ASI eksklusif yaitu mampu meningkatkan daya tahan tubuh bayi. Hal tersebut dikarenakan kandungan antibodi dalam ASI yang dapat melindungi bayi dari serangan penyakit. Penelitian sebelumnya melaporkan bahwa terdapat pengaruh yang signifikan antara pemberian ASI eksklusif dengan kejadian diare pada bayi di kota Padang, dimana bayi yang mendapatkan ASI eksklusif lebih sedikit mengalami diare dibandingkan bayi yang tidak mendapat ASI eksklusif (Rahmadhani, Lubis, \& Edison, 2013). Hasil penelitian yang dilakukan oleh Nurmiati \& Besral (2008) menunjukan bahwa durasi pemberian ASI sangat mempengaruhi ketahanan hidup bayi di 
Indonesia. Bayi yang disusui dengan durasi 6 bulan atau lebih memiliki ketahanan hidup 33,3 kali lebih baik daripada bayi yang disusui kurang dari 4 bulan, dan bayi yang disusui dengan durasi 4-5 bulan memiliki ketahanan hidup 2,6 kali lebih baik daripada bayi yang disusui kurang dari 4 bulan. ASI eksklusif dilaporkan mampu mengurangi angka kesakitan dan kematian pada bayi karena pneumonia (Lamberti et al., 2013).

Cakupan ASI eksklusif di Indonesia pada tahun 2014 masih cukup rendah dibandingkan dengan manfaatkan yang didapatkannya. Berdasarkan Profil Kesehatan Indonesia 2014 bayi yang mendapat ASI eksklusif hanya sebanyak 52,3 persen, sedangkan target cakupan sebesar 80 persen (Kementerian Kesehatan, 2015). Cakupan ASI Eksklusif di Kabupaten Cilacap hanya sebesar 36,16 persen angka ini lebih rendah dari akupan ASI eksklusif nasional (Dinkes Kabupaten Cilacap, 2015). Keberhasilan ASI eksklusif dipengaruhi oleh beberapa faktor salah satunya adalah faktor dukungan dari tenaga kesehatan termasuk bidan. Peran bidan dalam mendukung ASI eksklusif antara lain melalui upaya promosi ASI eksklusif yang dimulai dari masa kehamilan. Penelitian yang dilakukan di Puskesmas Margangsang Yogyakarta menunjukan terdapat pengaruh yang bermakna antara konseling ASI eksklusif terhadap pemberian ASI dan kolostrum selama 3 hari postpartum (Fatayati \& Mufdlillah, 2011). Dukungan lain yang dapat diberikan bidan yaitu mempersiapkan ibu untuk dapat menyusui dengan baik dengan melakukan perawatan payudara selama kehamilan. Perawatan payudara yang dilakukan pada masa kehamilan bertujuan untuk menjaga kebersihan payudara, kesiapan puting dan memastikan ASI sudah keluar sebelum kelahiran bayi. Bidan juga dapat memfasilitasi ibu untuk melakukan inisiasi menyusu dini (IMD) pada satu jam pertama setelah bayi lahir, tidak memberikan susu formula dan melakukan rawat gabung (Sabati, 2015). Penelitian ini bertujuan untuk menganalisis peran bidan dalam pemberian ASI eksklusif di Kabupaten Cilacap meliputi promosi ASI eksklusif, perawatan payudara selama hamil dan pelaksanaan IMD.

\section{METODE}

Penelitian ini merupakan penelitian dengan pendekatan crossectional. Penelitian ini dilakukan di Kabupaten Cilacap pada tahun 2014 pada 220 ibu dari bayi berusia 6-12 bulan di wilayah Puskesmas Cilacap Selatan I. Pemilihan Wilayah Puskesmas Cilacap Selatan I didasari dari cakupan ASI eksklusif tertinggi di seluruh Puskesmas di wilayah Kota Cilacap dengan cakupan ASI eksklusif sebesar 39,88 persen. Sampel penelitian diambil dengan cara cluster random samping berdasarkan wilayah posyandu.

Instrumen yang digunakan dalam penelitian ini adalah kuesioner yang terdiri dari dua bagian. Kuesioner yang pertama mengenai peran bidan meliputi, promosi ASI eksklusif, perawatan payudara dan pelaksanaan inisiasi menyusui dini (IMD). Kuesioner yang kedua merupakan kuesioner yang digunakan untuk mengidentifikasi pemberian ASI eksklusif. Analisis data menggunkan SPSS dengan uji Chi square dengan tingkat kemaknaan $\mathrm{p}<$ 0,05 dan kekuatan pengaruh dilihat berdasarkan besar risk estimate.

\section{HASIL DAN PEMBAHASAN}

Hasil penelitian terhadap 220 ibu yang memiliki balita usia 6-12 bulan tentang peran bidan dalam pemberian ASI eksklusif disajikan pada tabel 1. Berdasrkan tabel 1 sebagian besar bidan telah melakukan promosi ASI eksklusif (80,9 persen), ibu hamil yang dilakukan perawatan payudara sebesar 25,9 persen dan pelaksanaan IMD hanya dilakukan oleh 9,1 persen bidan. Ibu yang memberikan ASI eksklusif kepada bayinya cukup kecil yaitu sebesar 28,8 persen. 
Tabel 1. Distribusi Frekuensi Peran Bidan dalam Pemberian ASI Eksklusif

\begin{tabular}{lcc}
\hline \multicolumn{1}{c}{ Peran Bidan } & n & \% \\
\hline Promosi ASI Eksklusif & & \\
Tidak Dilakukan & 42 & 19,1 \\
Dilakukan & 178 & 80,9 \\
Perawatan Payudara & & \\
$\quad$ Tidak Dilakukan & 163 & 74,1 \\
$\quad$ Dilakukan & 58 & 25,9 \\
IMD & & \\
Tidak Dilakukan & 200 & 90,9 \\
$\quad$ Dilakukan & 20 & 9,1 \\
Keberhasilan ASI Eksklusif & & \\
Tidak Eksklusif & 158 & 71,8 \\
$\quad$ ASI Eksklusif & 62 & 28,2 \\
\hline
\end{tabular}

Tabel 2 menunjukkan pengaruh promosi ASI eksklusif terhadap pemberian ASI eksklusif berdasarkan nilai $\mathrm{p}$ tidak signifikan namun berdasarkan nilai OR, ibu yang tidak mendapatkan promosi ASI eksklusif akan berisiko 1,5 kali lebih besar tidak memberikan ASI eksklusif pada bayinya dibandingkan ibu yang mendapatkan promosi ASI eksklusif. Pengaruh tersebut diaktegorikan dalam berpengaruh sedang. $(\mathrm{OR}=1,55 ; \quad \mathrm{Cl} 95$ persen $=0,69-3,47$; $\mathrm{p}=0,279)$. Perawatan payudara $(\mathrm{OR}=6,35 ; \mathrm{Cl}$ 95 persen $=3,27-12,31 ; \mathrm{p}=0.001$ ) dan IMD $(\mathrm{OR}=11,56 ; \quad \mathrm{Cl} 95$ persen=4,04-33,07; $\mathrm{p}=0.001$ ) berpengaruh kuat dan secara statistik signifikan terhadap ASI Ekslusif. Ibu yang tidak mendapatkan perawatan payudara selama kehamilan akan meningkatkan risiko 6 kali lebih besar untuk tidak memberikan ASI eksklusif kepada bayinya. Tidak dilakukannya IMD pada satu jam pertama setelah bayi lahir akan meningkatkan risiko bayi tidak mendapat ASI eksklusif 11,5 kali lebih besar dibandingkan dengan ibu yang melakukan IMD.

Tabel 2

Analisis Bivariat Peran Bidan dalam Pemberian ASI Eksklusif

\begin{tabular}{|c|c|c|c|c|c|c|c|c|}
\hline \multirow{3}{*}{ Variabel Independen } & \multicolumn{4}{|c|}{ Pemberian ASI Ekslusif } & \multirow{3}{*}{ OR } & \multicolumn{2}{|c|}{ CI $(95 \%)$} & \multirow{3}{*}{ p-value } \\
\hline & \multicolumn{2}{|c|}{$\begin{array}{c}\text { Tidak } \\
\text { Eksklusif }\end{array}$} & \multicolumn{2}{|c|}{ ASI Eksklusif } & & \multirow{2}{*}{$\begin{array}{c}\text { Batas } \\
\text { Bawah }\end{array}$} & \multirow{2}{*}{$\begin{array}{c}\text { Batas } \\
\text { Atas }\end{array}$} & \\
\hline & $\mathbf{n}$ & $\%$ & $\mathbf{n}$ & $\%$ & & & & \\
\hline \multicolumn{9}{|l|}{ Promosi ASI Esklsusif } \\
\hline Tidak Dilakukan & 33 & 15 & 125 & 56,8 & 1,55 & 0,69 & 3,47 & 0,279 \\
\hline Dilakukan & 9 & 4,1 & 53 & 24,1 & & & & \\
\hline \multicolumn{9}{|l|}{ Perawatan payudara } \\
\hline Tidak Dilakukan & 134 & 60,9 & 24 & 10,9 & 6,35 & 3,27 & 12,31 & 0,001 \\
\hline Dilakukan & 29 & 13,2 & 33 & 15 & & & & \\
\hline \multicolumn{9}{|l|}{ IMD } \\
\hline Tidak Dilakukan & 153 & 69,5 & 5 & 2,3 & 11,56 & 4,04 & 33,07 & 0,001 \\
\hline Dilakukan & 45 & 20,5 & 17 & 7,7 & & & & \\
\hline
\end{tabular}

Berdasarkan hasil penelitian keberhasilan ASI eksklusif di Puskesmas Cilacap Selatan I hanya sebesar 28,2 persen. Beberapa faktor dapat menyebabkan keberhasilan ASI eksklusif rendah, salah satunya yaitu kurangnnya promosi ASI eksklusif oleh tenaga kesehatan. Hal tersebut tampak dari hasil penelitian dimana 15 persen ibu yang tidak memberikan ASI eksklusif tidak mendapat promosi ASI eksklusif dari tenaga kesehatan. Promosi ASI eksklusif merupakan salah satu upaya untuk meningkatkan pengetahuan dan kesadaran ibu tentang manfaat dan pentingnya ASI eksklusif (Coutinho et al., 2014). Berdasarkan hasil penelitian Gusti D, et al. (2011) ibu yang mendapatkan promosi ASI eksklusif menggunkan metode konseling mengalami kenaikan rata-rata pengetahuan dan sikap tentang ASI Eksklusif (Gusti, Bachtiar, \& Masrul, 2011). Promosi ASI Eksklusif dapat dilakukan sedini mungkin semenjak ibu dinyatakan hamil, dengan demikian maka informasi yang bisa diberikan kepada ibu 
akan semakin banyak. Dalam penelitian ini pengaruh promosi ASI eksklusif secara statistik tidak signifikan namun dilihat dari angka risk estimate ibu yang tidak mendapat promosi ASI ekslusif akan berisiko 1,5 kali tidak memberikan ASI eksklusif dibanding dengan ibu yang mendapatkan promosi ASI eksklusif.

Hasil penelitian tersebut dapat disebabkan karena perilaku dalam memberikan ASI eksklusif tidak hanya dipengaruhi oleh pengetahuan ibu tetapi juga dipengaruhi oleh orang terdekat ibu seperti suami, kakak perempuan atau ibunya. Ibu yang mendapatkan dukungan dari keluarga baik berupa nasihat, pengarahan maupun informasi yang cukup terkait dengan ASI eksklusif dapat meningkatkan motivasi ibu untuk memberikan ASI ekslusif pada bayinya lebih lama dibanding yang tidak mendapat dukungan. Penelitian lain menyebutkan ibu yang mendapat dukungan suami akan berpeluang dua kali memberikan ASI eksklusif dibandingkan ibu yang tidak mendapat dukungan suami (Nurlinawati, Sahar, \& Permatasari, 2016). Berdasarkan hal tersebut maka sasaran promosi ASI eksklusif oleh bidan tidak hanya ibu namun juga perlu melibatkan suami dan keluarga. Dengan demikian materi promosi ASI eksklusif tidak hanya mengenai pentingnya ASI eksklusif dan proses menyusui tetapi juga disertai penjelasan tentang bagaimana suami dan keluarga dapat berperan aktif untuk mendukung ibu dalam memberikan ASI eksklusif.

Perawatan payudara pada saat kehamilan bertujuan untuk menjaga kebersihan payudara, mempersiapkan puting dan memastikan produksi ASI sebelum bayi lahir. Berdasarkan hasil penelitian perawatan payudara pada ibu hamil secara signifikan berpengaruh kuat terhadap pemberian ASI eksklusif (Lee \& Thomas, 2008). Ibu yang tidak dilakukan perawatan payudara selama hamil oleh bidan akan berpeluang 6 kali lebih besar tidak memberikan ASI eksklusif dibandingkan dengan ibu yang dilakukan perawatan payudara. Permasalahan menyusui yang sering muncul pada saat awal bayi lahir adalah belum keluarnya ASI sehingga bayi tidak dapat langsung menyusu. Selain itu puting yang mendatar juga merupakan masalah yang sering ditemui dalam proses menyusui. Hal tersebut dapat terjadi apabila tidak dilakukan perawatan payudara pada saat kehamilan. Dengan melakukan perawatan payudara selama hamil maka puting susu yang mendatar dapat dilakukan stimulasi agar menonjol. Demikian juga dengan produksi ASI, yang dapat mulai dirangsang pada ahir kehamilan, bahkan pada beberapa ibu ASI sudah keluar pada trimester II kehamilan. ASI yang tidak lancar akan menyebabkan bayi menjadi rewel dan hal tersebut sering kali menjadi faktor yang mendorong ibu pada akhirnya tidak memberikan ASI eksklusif.

Meskipun pengaruh perawatan payudara terhadap keberhasilan ASI eksklusif bermakna secara statistik, namun berdasarkan hasil penelitian bidan yang melakukan perawatan payudara selama kehamilan hanya sebanyak 25,9 persen. Hasil tersebut mungkin disebabkan karena sebagian besar bidan hanya memberikan pendidikan kesehatan tentang cara melakukan perawatan payudara tanpa mempraktikan langsung kepada ibu sehingga keterampilan ibu untuk melakukan perawatan payudara masih kurang dan apada akhirnya ibu tidak melakukan perawatan payudara sendiri. Hal ini sejalan dengan penelitian Indrasari N (2016) dimana ibu yang memiliki pengetahuan yang baik akan berpeluang 4,5 kali lebih baik dalam melakukan perawatan payudara dibanding ibu dengan pengetahuan rendah (Indrasari, 2016).

IMD merupakan proses membiarkan bayi dengan nalurinya sendiri menyusu dalam 1 jam pertama setelah lahir, bersamaan dengan kontak kulit (skin to skin contact) antara kulit ibu dengan kulit bayi (Khanal, Scott, Lee, Karkee, \& Binns, 2015). Hasil Penelitian menunjukan terdapat pengaruh yang kuat antara proses IMD dengan pemberian ASI 
eksklusif, dimana ibu yang tidak dilakukan IMD akan menaikan peluang tidak ASI eksklusif sebesar 11,5 kali. Hasil penelitian ini sejalan dengan hasil penelitian di Jepang oleh Nakao et al. (2008), yang menyebutkan bahwa keberhasilan ASI eksklusif sampai empat bulan berhubungan dengan IMD dalam dua jam pertama kehidupan (Nakao, Moji, Honda, \& Oishi, 2008).

Berdasarkan hasil penelitian bidan yang melakukan IMD hanya sebesar 9 persen. Hal tersebut mungkin disebabkan kurangnya keterampilan dan motivasi bidan dalam melakukan IMD. Penelitian di RSUPN Dr. Cipto Mangunkusumo menunjukkan adanya hubungan yang signifikan antara bidan yang memiliki sikap positif terhadap IMD dengan penerapan praktik IMD. Bidan yang bersikap positif akan lebih cenderung untuk melakukan IMD (Fikawati \& Syafiq, 2010). Faktor lain yang mungkin menyebabkan rendahnya IMD dikarenakan pelaksanaan IMD yang tidak sampai satu jam atau tidak sampai bayi mampu menyusu sendiri, karena bayi segera mendapat asuhan selanjtnya seperti pemberian salep mata, injeksi Vitamin $\mathrm{K}$ dan asuhan lainnya. Belum keluarnya ASI dan ketidak siapan ibu karena kurangnya pengetahuan ibu tentang IMD juga dapat menyebabkan bidan tidak melakukan IMD

\section{KESIMPULAN DAN SARAN}

Promosi ASI eksklusif berpengaruh sedang terhadap ASI eksklusif sedangkan perawatan payudara dan IMD berpengaruh kuat terhadap pemberian ASI Eksklusif. Bidan perlu meningkatkan perannya dalam melakukan promosi ASI ekskluisf dimana sasaran promosi ASI eksklusif tidak hanya pada ibu tetapi juga perlu melibatkan suami dan keluarga. Bidan juga perlu meningkatkan perawatan payudara pada ibu hamil sehingga proses laktasi setelah persalinan dapat berjalan dengan lancar. Begitu pula dengan pelaksanaan IMD, bidan perlu mengedukasi ibu tentang pelaksanaan IMD sebelum proses persalinan sehingga pada saat ibu bersalin IMD dapat dilakukan dengan baik. 


\section{DAFTAR PUSTAKA}

Coutinho, S. B., Lira, P. I. C., Lima, M. C., Frias, P. G., Eickmann, S. H., \& Ashworth, A. (2014). Promotion of exclusive breast-feeding at scale within routine health services: Impact of breast-feeding counselling training for community health workers in Recife, Brazil. Public Health Nutrition, 17(4), 948-955.

https://doi.org/10.1017/S13689800130 01833

Dinkes Kabupaten Cilacap. (2015). Profil Kesehatan Kabupaten Cilacap Tahun 2014. Cilacap: Dinkes Kab. Cilacap.

Fatayati, A., \& Mufdlillah. (2011). Pengaruh Konseling ASI Eksklusif Pada Ibu Hamil Trimester III Terhadap Pemberian ASI Dan Kolostrum Selama 3 Hari Postpartum Di Puskesmas Mergangsan Yogyakarta. STIKES Aisyah Jogyakarta.

Fikawati, S., \& Syafiq, A. (2010). Kajian implementasi dan kebijakan air susu ibu ekslusif dan inisiasi menyusui dini di Indonesia. Makara Kesehatan, 14(1), 17-24.

Gusti, D., Bachtiar, H., \& Masrul. (2011). Promosi Asi Ekslusif Memakai Metode Konseling Dengan Penyuluhan Terhadap Pengetahuan Dan Sikap Pada Ibu Menyusu. Jurnal Kesehatan Masyarakat, 6(94), 4-9.

Indrasari, N. (2016). Hubungan Pengetahuan Ibu Hamil Dengan Pelaksanaan Perawatan Payudara. Jurnal Keperawatan, 12(1), 1-7.

Kementerian Kesehatan. (2015). Profil Kesehatan Indonesia 2014. Kementerian Kesehatan Republik Indonesia (Vol. https://doi.org/10.1037/00223514.51.6.1173

Khanal, V., Scott, J. A., Lee, A. H., Karkee,
R., \& Binns, C. W. (2015). Factors associated with early initiation of breastfeeding in Western Nepal. International Journal of Environmental Research and Public Health, 12(8), 9562-9574.

https://doi.org/10.3390/ijerph12080956 2

Lamberti, L., Zakarija-Grković, I., Fischer Walker, C., Theodoratou, E., Nair, H., Campbell, H., \& Black, R. (2013). Breastfeeding for reducing the risk of pneumonia morbidity and mortality in children under two: a systematic literature review and meta-analysis. MBC Public Health, 13(3), 2-8.

Lee, S. J., \& Thomas, J. (2008). Antenatal breast examination for promoting breastfeeding. Cochrane Database of Systematic Reviews. https://doi.org/10.1002/14651858.CD0 06064.pub2

Nakao, Y., Moji, K., Honda, S., \& Oishi, K. (2008). Initiation of breastfeeding within 120 minutes after birth is associated with breastfeeding at four months among Japanese women: A self-administered questionnaire survey. International Breastfeeding Journal, 3(1), 1-7. https://doi.org/10.1186/17464358-3-1

Novita, L., Gurnida, D. A., \& Garna, H. (2008). Perbandingan Fungsi Kognitif Bayi Usia 6 Bulan yang Mendapat dan yang Tidak Mendapat ASI Eksklusif. Sari Pediatri, 9(6), 429-434. https://doi.org/http://dx.doi.org/10.1423 8/sp9.6.2008.429-34

Nurlinawati, Sahar, J., \& Permatasari, H. (2016). Dukungan Keluarga Terhadap Pemberian ASI Eksklusif Pada Bayi di Kota Jambi. JMJ, 4(1), 77-86.

Nurmiati, \& Besral. (2008). Pengaruh Durasi Pemberian ASI Terhadap Ketahanan Hidup Bayi di Indonesia. Makara Kesehatan, 12(2), 47-52. 
Rahmadhani, E. P., Lubis, G., \& Edison. (2013). Hubungan Pemberian ASI Eksklusif dengan Angka Kejadian Diare Akut pada Bayi Usia 0-1 Tahun di Puskesmas Kuranji Kota Padang. Jurnal Kesehatan Andalas, 2(2), 6266.

Sabati, M. R. (2015). Peran Petugas Kesehatan Terhadap Keberhasilan Pemberian ASI Eksklusif. Jurnal of Nutrition Collage, 4(2), 526-533.

Septikasari, M., Akhyar, M., \& Wiboworini, B. (2016). Effect of Gestational Biological, Social, Economic Factors on Undernutrition in Infants 6-12 Months in Cilacap. Indonesian Journal of Medicine, 1(3), 183-193. https://doi.org/https://doi.org/10.26911/ theijmed.2017.02.01.06 